\title{
HORIZONTAL AND VERTICAL FDI SPILLOVERS: RECENT EVIDENCE FROM THE CZECH REPUBLIC
}

\author{
Juraj Stančík
}
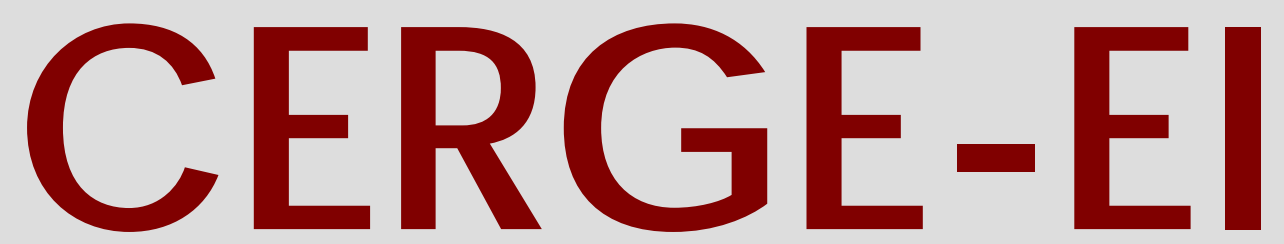

Charles University CenterforEconomic Research and Graduate Education Academy of Sciences of the Czech Republic Ec onomic s Institute 


\title{
Working Paper Series $\quad 340$ (ISSN 1211-3298)
}

\section{Horizontal and Vertical FDI Spillovers: Recent Evidence from the Czech Republic}

\author{
Juraj Stančík
}

CERGE-EI

Prague, September 2007 
ISBN 978-80-7343-139-6 (Univerzita Karlova. Centrum pro ekonomický výzkum a doktorské studium)

ISBN 978-80-7344-128-9 (Národohospodářský ústav AV ČR, v.v.i.) 


\title{
Horizontal and Vertical FDI Spillovers: Recent Evidence from the Czech Republic*
}

\author{
Juraj Stančík \\ CERGE-EI ${ }^{\dagger}$
}

September 2007

\begin{abstract}
This paper analyzes the effects of foreign direct investment on the sales growth rate of domestic companies in the Czech Republic. Using firmlevel panel data from 1995 to 2003, it studies both horizontal and vertical spillovers. The study allows for the lagged nature of spillovers and pays attention to the potential endogeneity of FDI with respect to future industry growth. The results suggest that domestic companies are mostly suffering in the presence of foreign companies, especially in upstream sectors. Negative horizontal and forward spillovers are present mainly in recent years. Time sensitivity is revealed for horizontal spillovers.
\end{abstract}

\begin{abstract}
Abstrakt
Ciel'om tejto štúdie je analýza vplyvu priamych zahraničných investícií na rast tržieb domácich firiem v Českej republike. S využitím firemných dát z obdobia 1995-2003 skúma horizontálne a vertikálne vplyvy plynúce zo zahraničných investícií. Tieto efekty sú analyzované aj vzhl'adom na roky, ked' boli jednotlivé investície zrealizované. Pozornost' venujem aj potenciálnej endogenite PZI vzhl'adom na budúci rast v jednotlivých odvetviach. Z výsledkov vyplýva, že domáce firmy strácajú v prítomnosti zahraničných investorov, najmä tie v dodávatel'ských sektoroch. Záporné horizontálne a vertikálne efekty sa prejavujú najmä ku koncu skúmaného obdobia. Časová senzitívnost' je preukázaná iba pre horizontálne efekty.
\end{abstract}

Keywords: productivity, growth, spillovers, FDI, ownership JEL classification: C23, D24, D57, L6

*I would like to thank Štěpán Jurajda for valuable consultations on this research, Jan Hanousek and Evžen Kočenda for providing data and useful comments, and Peter Katuščák for valuable comments. I am grateful also to Richard Stock for editing the manuscript. Financial support from GAČR grant No. 402/06/1293 is gratefully acknowledged.

${ }^{\dagger}$ A joint workplace of the Center for Economic Research and Graduate Education, Charles University, Prague, and the Economics Institute of the Academy of Sciences of the Czech Republic. Address: CERGE-EI, P.O. Box 882, Politických vězňů 7, Prague 1, 111 21, Czech Republic 


\section{Introduction}

Foreign direct investment (FDI) is a driving force of growth for every developing economy. It brings in new capital, technology, and know-how. This investment usually comes either in the form of a greenfield project, where a new plant is built, and therefore a new company formed or in the form of foreign capital inflow to an existing domestic company. In both cases, this company is typically characterized by higher productivity and competitiveness (Javorcik and Arnold 2005).

Besides these direct effects from FDI, there are also a variety of indirect effects. The entry of any company with increased productivity should naturally encourage other companies within the same sector to improve their performance and competitiveness. Increasing the efficiency of the production process can happen by copying new technologies or by hiring trained workers and managers from foreign-owned companies (Javorcik 2004). On the other hand, those domestic companies that are not able to catch up with the increased performance of other companies within the sector may be crowded out of the market. In general, these changes are referred to as horizontal spillovers.

However, companies from sectors other than that of the foreign enterprise might be affected by its presence as well if they are in direct business contact with it. This includes companies that supply or provide services for foreign firms, as well as companies that are supplied by foreign firms. It is likely that foreign companies require higher standards from their suppliers. On the other hand, it is also likely that higher standards are provided by foreign companies to domestic companies as well, which might improve the domestic companies' efficiency and performance. In general, these changes are referred to as vertical spillovers.

One of the highest priorities of most transition and developing countries is to present themselves as attractive places for investment. Governments in these countries compete to attract foreign investors by offering them various advantages. The Czech Republic is not an exception. In 1998 its government approved a system 
of subsidies for foreign investors that was supposed to increase the competitiveness of Czech industry. One of the supporting arguments was that foreign investors would help other domestic companies to improve. However, the actual impact on them is questionable.

Although the literature studying the effects of FDI on domestic companies is quite comprehensive and there are numerous empirical studies focusing on transition as well as developed countries (Aitken and Harrison [1999]; Kinoshita [2000]; Haskel et al. [2002]; Damijan et al. [2003b]; Javorcik [2004]; and Kosová [2004]), their findings are ambiguous and in many cases contradictory, even for the same countries. These results are sensitive to each country's unique experience, quality of data, chosen time period or applied methodology.

In particular, most of the studies on the Czech Republic suffer from small samples and from their focus on the early transition period. Early transition (i.e., 1991-1996) is characterized by mass privatization and unclear ownership structures, whereas the main boom of foreign investment came in and after 1998 (see Figure 1 in the Appendix), which is the last sample year in almost every previous study about the Czech Republic. ${ }^{1}$ Therefore, there is no surprise that previous studies often did not succeed in finding any significant spillover effects.

The goal of this paper is therefore to analyze the effects of FDI on the performance of domestic companies in the Czech Republic. Particularly, I study the gains from FDI within the same sector as well as the gains through vertical linkages. The main advantage of the present paper over the previous literature is that besides the "standard" horizontal impact, I allow also for backward and forward vertical spillovers. Moreover, I employ up-to-date data that cover the period 1995-2003. I also shed light on the sources of identification, study the time structure of these effects and pay attention to the potential endogeneity of FDI with respect to future industry growth.

\footnotetext{
${ }^{1}$ Kosová (2004) is the only exception here with her time span ending in 2001.
} 
Contrary to expectations and the arguments supporting FDI subsidies, this paper finds that foreign investors contribute negatively to the performance of domestic companies, especially to those in upstream sectors. In other words, domestic companies supplying foreign-owned firms are negatively affected by the presence of foreign investors as a negative backward spillover effect is found. Since foreign investors prefer to import their supplies from abroad, Czech supplying companies oriented mainly on domestic markets suffer. This effect becomes even more evident after accounting for the endogeneity of FDI. A negative horizontal spillover effect is found as well, although it lags behind actual investment by 2 years. Thus, domestic companies are not able to sustain increased competition within a sector and their sales growth decreases.

The paper is structured as follows. The second section deals with the previous studies relevant for this research. The third section contains the data description. My research strategy is explained in the fourth section where one can also find all the empirical results. The last section concludes.

\section{Literature Review}

This section includes a review of several key papers about FDI spillovers. At first, I present three studies not on the Czech Republic that I consider to have a significant value-added over the previous literature. They are interesting mainly by their pioneering work in studying horizontal spillovers, the per-job values of these spillovers, or vertical spillovers. The second half of this section then looks more closely at the papers concerning the Czech Republic.

One of the first studies investigating the benefits for domestic companies from FDI using company-level panel data is Aitken and Harrison (1999). ${ }^{2}$ In their study they use a sample of around 5, 000 companies in Venezuela during the years 19761989. They find a positive effect of FDI on domestic companies with less than

\footnotetext{
${ }^{2}$ This statement is based on the summary paper by Görg and Greenaway (2003).
} 
50 employees and a small negative effect of FDI on all domestic companies. They further claim that the whole positive effect of the presence of foreign enterprises is gained by joint ventures with foreign capital. According to the authors, the overall effect is thus only slightly positive. They explain this conclusion by the fact that Venezuela might not be developed enough to gain from FDI yet, and they expect the effect to become more prevalent in the long run after the exit of weaker firms.

Haskel et al. (2002) concerns the spillover effects from FDI to domestic companies. They research this using a sample of more than $90 \%$ of all manufacturing firms in the UK during the period 1973-1992. According to their results, there is a positive horizontal spillover effect on total factor productivity (TFP) within sectors, but they fail to find any significant effect within a region. They further claim that it takes some time for spillovers to permeate the domestic companies. Additionally, they estimate a per-job value of these spillovers and compare it with government new-job subsidies to foreign enterprises. The results of this comparison suggest that in most cases these subsidies exceed per-job values, even several times. However, as the authors add, it is necessary to keep in mind that there are a variety of other positive effects of FDI spillovers that cannot be included into any economic estimation, especially social welfare.

Javorcik (2004) contains a number of improvements on the existing literature. Besides the FDI effect on domestic companies and horizontal spillovers, she stresses the role of vertical spillover effects, sheds some light on the determinants of this backward linkage, and implements various innovative methodological steps. Her research is based on a sample of $85 \%$ of all Lithuanian companies in the period 1996-2000. She does not find any significant horizontal spillover effect or effects within a region; however, she finds a positive significant vertical spillover effect of FDI on domestic companies. As regards the determinants of spillovers, she claims that the effect is more prevalent when foreign-owned companies are domestic rather than export-oriented, and there is no difference in magnitude between the effects 
from partially or fully foreign-owned companies.

There are several company-level studies on the Czech Republic. Djankov and Hoekman (2000) study the impact of FDI on the TFP growth of recipient firms and find that this impact is positive and significant. On the other hand, the effect of joint ventures is less positive and even becomes insignificant. As regards the spillover effects, they find a negative horizontal spillover effect of FDI and joint ventures, taken together, on domestic companies. The impact of just FDI is also found to be negative but insignificant. However, the credibility of their result is undermined by the fact that they use a sample of only 513 firms and the period of 1992-1996, which is a period characterized by mass privatization and unclear ownership structures.

Kinoshita (2000) uses a slightly better data set: 1,217 manufacturing firms and the period 1995-1998. She finds no significant technology spillover effect of joint ventures or FDI on productivity growth neither within the firm nor within the industry. On the other hand, the author contends that this effect varies hugely across sectors and is positive and significant for oligopolistic sectors, such as radio and TV or electrical machinery. Kinoshita further examines the two roles of the firm's R\&D - innovation and absorptive capacity. She claims that the latter is far more important. According to her results, the effects of FDI are significant for firms that perform their own R\&D - the horizontal spillover is positive and the direct effect is negative, whereas the effect of just $R \& D$ remains insignificant.

Jarolím (2001) concentrates mainly on the performance of foreign-owned companies, but he examines also the horizontal spillover effects of FDI on domestic companies within the same sector. For this purpose, he uses a sample of 3,152 enterprises from the manufacturing sector over the period 1993-1998. In line with the previous literature, he shows that foreign-owned companies are characterized by higher TFP. However, he does not find any significant horizontal spillover effects. Moreover, he compares the performance of greenfield ventures with foreign 
acquisitions and concludes that the former perform significantly better. The author explains this difference by the ineffectiveness of formerly state-owned companies, which foreign investors have to restructure after the acquisition, and which slows down the process of technology transfer.

Damijan et al. (2003a) examine the direct effect of FDI, intra-industry knowledge spillovers from FDI and the impact of firms' own R\&D accumulation on productivity growth using a sample of eight transition countries ${ }^{3}$ in the period 19941998. Regarding the Czech Republic, they use a sample of 1,115 manufacturing companies and find a positive direct effect of FDI on domestic recipient companies. Intra-industry knowledge spillovers are found to be insignificant, but, similarly to Kinoshita (2000), their significance increases when controlling for a firm's own R\&D. Surprisingly, the productivity growth of Czech companies that perform their own R\&D decreases with a foreign presence in the industry. Moreover, according to their results, most domestic firms' knowledge and technology improvements are gained from their trade partners abroad.

In a closely related study Damijan et al. (2003b) use the sample of Damijan et al. (2003a), add Lithuania and Latvia, and study the period 1995-1999. Their analysis incorporates not only horizontal but also vertical spillovers. They conclude that vertical spillover effects are more important than horizontal effects. Particularly, both of these effects are positive in the Czech Republic. In the case of horizontal spillovers, these new findings contradict their previous study. Especially, when the results claim that companies with foreign presence have lower productivity growth than companies without foreign capital. The contribution of a firm's own R\&D is not confirmed to be significant, which is also in contrast to their previous study. They do not provide a sufficient explanation for this contradiction in their research and they do not even compare or mention their previous study in connection with their current results. One can only assume that this inconsistency might be caused

\footnotetext{
${ }^{3}$ Bulgaria, Czech Republic, Estonia, Hungary, Poland, Romania, Slovakia, and Slovenia.
} 
by either the different estimation approach (current GMM vs. previous OLS) or the shift in the time period.

Kosová (2004) studies the effect of FDI on the productivity of domestic firms and the crowding-out effect from the presence of foreign companies. She uses a sample of 9,986 Czech companies from all sectors covering the period 1994-2001. She finds a positive effect of foreign capital presence on domestic firms' growth and survival. She claims that exit rates are lower for companies in industries with a foreign presence. Moreover, she finds that a positive intra-industry technological spillover effect is present in more technologically advanced industries.

Finally, Kosová and Ayyagari (2006) shift a bit away from the line of the previous literature studying the effects on productivity and rather deal with the impact of FDI on domestic entrepreneurship. They find that foreign presence contributes positively to the entry rates of domestic companies through both horizontal and vertical spillovers. Although both of these effects are statistically significant, they claim the dominance of vertical spillovers dominate over horizontal spillovers, especially through forward linkages. For this research they use a sample of 9,979 Czech companies covering the period 1994-2000.

Since these studies provide highly mixed results, they are summarized in Table 1. Looking at this table, one can see that every previous study about the Czech Republic has a shortcoming. First, the employed samples are rather small, except the last two papers. Second, most of these studies examine the period before 1999 when there was almost no FDI inflow into the Czech Republic, at least compared to the following years. Thus, it is no surprise that these studies often do not succeed in finding significant spillovers. Third, most of the previous literature is limited to manufacturing sectors only. However, it is likely that especially domestic companies from service sectors would be affected by the presence of foreign investors. Unlike manufacturing companies, these companies are not able to export their services abroad and they are limited to the domestic market only. Fourth, there is 
every kind of horizontal spillover found in the previous literature - negative, insignificant, and positive. Fifth, only two papers study vertical spillovers. Finally, although none of the previous five objections is related to Kosová and Ayyagari (2006), their study is less relevant for this topic because they examine the impact of FDI on domestic entrepreneurship rather than on productivity or sales.

\section{Data}

The company-level annual data used here come from the ASPEKT database, which is a Czech source for the Amadeus database ${ }^{4}$ and is widely used in empirical research (Earnhart and Lízal [2002]; Hanousek et al. [2005]; Bena and Hanousek [2006]). Financial data cover the period 1993-2004, include 24, 648 Czech firms in total and form an unbalanced panel, where the number of usable companies varies from almost 2,000 in 1993 to more than 17,000 in 2002. The ASPEKT database also provides information about companies' ownership structures. However, due to the limited availability of this information, the total number of companies is significantly reduced. Ownership information allows me to distinguish foreign companies from domestic ones. I interpret a company as foreign if it has at least $10 \%$ of its equity owned by a foreign investor. ${ }^{5}$ In contrast to most previous studies, I do not limit the analysis only to manufacturing sectors. With a few exceptions I employ data from all sectors; only sectors with a strong regulatory role of the government are excluded (see the Appendix for details).

For studying vertical spillover effects, I employ inter-industry data (input-output matrices) that come from the Czech Statistical Office (CSO). A significant improvement over the existing literature ${ }^{6}$ is that I have these matrices available for every year during 1995-2003. All the previous studies use the assumption that these ma-

\footnotetext{
${ }^{4}$ Amadeus is a pan-European financial database.

${ }^{5}$ The same threshold is also used in the Czech National Bank official definition of FDI and in Damijan et al. (2003b) and Javorcik (2004).

${ }^{6}$ Damijan et al. (2003b), Javorcik (2004), or Kosová and Ayyagari (2006).
} 
trices do not change much over time. However, the opposite is true. Descriptive analysis reveals that for almost $30 \%$ of relations, ${ }^{7}$ the standard deviation over time is bigger than the mean value. As a consequence of these variations, in order to remove possible measurement errors, I use fitted values from these matrices instead. In other words, I still have a different input-output matrix for each year but these matrices now capture trends in supplying and demanding rather than just oscillating values.

After merging all variables and performing several cleaning and filling procedures, ${ }^{8}$ the resulting sample covers the period 1995-2003 and contains information about 4, 067 companies from 43 sectors, ${ }^{9}$ which accounts for 21,357 observations in total. An overview of the time, sector and ownership structure of the final sample is provided in Table 2 and Table 4. The number of companies varies from 1,336 in 1995 to 2, 788 in 2000. Foreign companies cover $25 \%$ of all observations. As regards sectors, most of the companies are from service sectors (56\%) and manufacturing sectors (38\%). Although I do not distinguish spillovers with respect to the type of entrance of foreign investors in this study, Table 4 also includes information about the structure of my sample regarding greenfields and takeovers. From the total 4, 067 companies, almost $18 \%$ are greenfields and $13 \%$ are acquisitions.

Finally, Table 3 shows the summary statistics of all the variables used in this research. Although inputs to production such as fixed assets of staff costs are increasing on average, sales of Czech companies are decreasing. As regards the ownership structure, the average share of a foreign investor in a Czech company is almost $19 \%$.

\footnotetext{
${ }^{7} \mathrm{~A}$ relation is a time series of the flow of goods and services from sector $X$ to sector $Y$ for the whole period 1995-2003. There are almost 7,000 such relations - for every combination of sectors $X$ and $Y$, as well as for the supply and demand relationship. These relations are used to generate a mean value and standard deviation for every time series.

${ }^{8}$ All of these procedures are described in the Appendix.

${ }^{9}$ 2-digit NACE classification (Classification of Economic Activities in the European Community) is used for sector distinguishing.
} 


\section{Research Approach and Estimation Results}

\subsection{Spillover Variables}

For the sake of continuity and comparison with previous studies, I follow the approach of Javorcik (2004) and create three spillover variables:

- The variable $H O R I Z_{j t}$, measuring the spillover effect within the same sector, represents the share of foreign capital invested in foreign companies in sector $j$ at time $t$ and is defined as

$$
H O R I Z_{j t}=\frac{\sum_{i: i \in j, F S_{i j t \geq 0.1}} F S_{i j t} F A_{i j t}}{\sum_{i: i \in j} F A_{i j t}},
$$

where $F S_{i j t}$ denotes the share of foreign capital in firm $i$ at time $t$ in sector $j$ and $F A_{i j t}$ denotes the fixed assets of firm $i$ at time $t$ in sector $j$.

- The variable $B A C K_{j t}$ represents the weighted share of foreign capital from all sectors that are supplied by sector $j$ at time $t$ and, conversely, the variable $F O R W_{j t}$ represents the weighted share of foreign capital from all sectors that supply sector $j$ at time $t$. They are defined as

$$
\begin{aligned}
& B A C K_{j t}=\sum_{k: k \neq j} \beta_{j k t} H O R I Z_{k t} \\
& F O R W_{j t}=\sum_{k: k \neq j} \beta_{k j t} H O R I Z_{k t},
\end{aligned}
$$

where $\beta_{x y t}$ stands for the fraction of output from sector $x$ supplied to sector $y$ at time $t . B A C K_{j t}$ measures the spillovers from the presence of foreign companies downstream and $F O R W_{j t}$ measures the spillovers from the presence of foreign companies upstream. 


\subsection{Theoretical Model}

The goal of this paper is to examine whether productivity growth is affected by the share of foreign capital within and across sectors. For this purpose, I follow the methodology in Haddad and Harrison (1993). They assume a production function with value-added $Y$ that is a function of two inputs, capital and labor:

$$
Y_{i j t}=A_{j t} f\left(K_{i j t}, L_{i j t}\right)
$$

The level of productivity is given by $A_{j t}$. It is assumed to vary across sectors $j$ and time $t$. By using total differential, taking logs, and using the fact that the value of the marginal product for each factor equals its cost, I now have

$$
\Delta \ln Y_{i j t}=\frac{\Delta A_{j t}}{A_{j t}}+\alpha_{1} \Delta \ln K_{i j t}+\alpha_{2} \Delta \ln L_{i j t}
$$

where $Y$ is value-added, $\frac{\Delta A}{A}$ is productivity growth, and $K$ and $L$ are capital and labor, respectively. The coefficients on the growth of labor and capital are simply their share in value-added. I test the hypothesis that productivity growth is affected by the share of foreign capital both within and across sectors by assuming that productivity growth can be decomposed into the following components:

$$
\frac{\Delta A_{j t}}{A_{j t}}=\alpha_{0}+\alpha_{3} \operatorname{HORIZ}_{j t}+\alpha_{4} B A C K_{j t}+\alpha_{5} F O R W_{j t}+\alpha_{Y}+\varepsilon_{i j t}
$$

where $H O R I Z, B A C K$, and $F O R W$ are spillover variables and the set of dummy variables, $\alpha_{Y}$, is introduced to control for year-specific effects. A stochastic disturbance term $\varepsilon_{i j t}$ is added to account for possible changes in productivity growth due to potential stochastic shocks at the firm or sector level over time. Combining (4) 
and (5) yields

$$
\begin{aligned}
\Delta \ln Y_{i j t}= & \alpha_{0}+\alpha_{1} \Delta \ln K_{i j t}+\alpha_{2} \Delta \ln L_{i j t}+\alpha_{3} H O R I Z_{j t}+\alpha_{4} B A C K_{j t}+ \\
& +\alpha_{5} F O R W_{j t}+\alpha_{Y}+\varepsilon_{i j t} .
\end{aligned}
$$

\subsection{Baseline Specification}

In order to study the horizontal and vertical spillover effects from FDI, the following modification of model (6) is estimated:

$$
\begin{aligned}
\Delta \ln S A L E S_{i j t}= & \gamma_{i}+\alpha_{1} \Delta \ln F A_{i j t}+\alpha_{2} \Delta \ln S C_{i j t}+\alpha_{3} H O R I Z_{j t}+\alpha_{4} B A C K_{j t}+ \\
& +\alpha_{5} F O R W_{j t}+\alpha_{Y}+\varepsilon_{i j t}
\end{aligned}
$$

where $S A L E S_{i j t}, F A_{i j t}$, and $S C_{i j t}$ stand for sales, fixed assets, and staff costs, respectively, for firm $i$ at time $t$ in sector $j$. The set of year dummy variables, $\alpha_{Y}$, is introduced also because sales, fixed assets, and staff costs are originally collected in nominal values. Moreover, each company has its own unobserved characteristics, e.g., better management or better technologies, which are assumed to be constant over time. For this reason, the variable $\gamma_{i}$ is included for capturing such firm characteristics. Model (7) is thus estimated with firms' fixed effects.

A positive value of the variable $H O R I Z_{j t}$ would imply that the presence of foreign companies in the sector has a positive impact on the productivity of domestic companies in the same sector. A positive value of the variable $B A C K_{j t}$ would imply that the presence of foreign companies has a positive impact on the productivity of those domestic companies that supply foreign companies. Similarly, a positive value of the variable $F O R W_{j t}$ would imply that the presence of foreign companies has a positive impact on the productivity of those domestic companies that are supplied by foreign companies. Since the goal of this paper is to study the effects on domestic companies, model (7), as well as all further models, are 
estimated on a sample of "always-domestic" companies only. This sample excludes companies that are foreign at any time during the sample frame. It allows one to study the pure spillover effects of FDI that are not affected by the better performance of either foreign companies or companies that are about to become foreign in the near future. However, for comparison, I estimate model (7) using the whole company population as well, including foreign companies.

Furthermore, in this kind of study, one has to be aware of the potential endogeneity of ownership on the firm level. In that case, foreign investors would acquire better domestic companies, while the worse ones would remain domestic. As a result, estimated coefficients would be biased towards negative values. In order to verify whether this is the case in this study, I run regression (7) on a sample of companies that are always-domestic plus the companies that will be acquired by foreign investors in the future during the period 1995-2003 but are still domestic now.

The estimates from these regressions are summarized in Table 5. The first column includes the estimated coefficients using a sample of always-domestic companies. The coefficients of capital and labor inputs are positive and significant, which is in line with expectations. However, the coefficient of the horizontal spillover variable is insignificant. This result partially corresponds to previous studies that mostly do not find any significant horizontal spillover effects. The coefficient of the forward spillover variable is insignificant as well. Only in the case of backward spillovers is the estimated coefficient significant and negative. For comparison, the only previous study about vertical spillover effects on productivity growth rate, Damijan et al. (2003b), which uses a sample of manufacturing companies from 1995-1999, implies a positive backward spillover effect. Thus, the result suggests that domestic companies supplying foreign companies are negatively affected by the presence of FDI: a 1\% increase in foreign capital in a downstream sector causes a decrease in the growth rate of the sales of supplying domestic companies by more 
than 1.5 percentage points.

Table 5 also presents the results from the estimation using a population of "to-now-domestic" companies in order to verify the potential endogeneity of foreign ownership. Nevertheless, according to the results, there is no cherry picking by foreign investors because the estimated coefficients have basically the same magnitudes as when the sample of "always-domestic" companies was employed. Thus, I do not allow for the endogeneity of foreign ownership on the firm level in the remaining part of this study.

\subsection{Does FDI Encourage Sales Growth or Vice Versa?}

The idea behind the previous estimations was that when a foreign investor comes to the Czech Republic and brings new technologies or expertise, domestic companies are consequently forced to improve themselves and become more efficient. However, the causality does not have to be so straightforward. Foreign investors usually come only to sectors where they expect some profit. These sectors are characterized either by the low productivity of most of the companies within that sector or by a boom. When the latter reason holds, an increase in sales growth is not entirely caused by foreign investors.

Therefore, in order to account for the possibility that foreign investors coming to the Czech Republic choose sectors with increasing sales growth, the following modification of model (7) is estimated:

$$
\begin{aligned}
\Delta \ln S A L E S_{i j t}= & \gamma_{i}+\alpha_{1} \Delta \ln F A_{i j t}+\alpha_{2} \Delta \ln S C_{i j t}+\alpha_{3} H O R I Z_{j t+1}^{\text {inflow }}+ \\
& +\alpha_{4} B A C K_{j t+1}^{\text {inflow }}+\alpha_{5} F O R W_{j t+1}^{\text {inflow }}+\alpha_{Y}+\varepsilon_{i j t},
\end{aligned}
$$

where the variable $H O R I Z_{j t+1}^{\text {inflow }}$ represents the share of the inflow of foreign capital into sector $j$ at time $t+1$ over the total amount of fixed assets within that sector in that year. The variable $B A C K_{j t+1}^{\text {inflow }}$ represents the weighted share of the inflow 
of foreign capital into all sectors that are supplied by sector $j$ at time $t+1$ and, conversely, the variable $F O R W_{j t+1}^{\text {inflow }}$ represents the weighted share of the inflow of foreign capital into all sectors that supply sector $j$ at time $t+1$. Thus, the definition is similar to the one from section 4.1 except that these are flow values and I am looking one period ahead. The results of the estimation of this model are summarized in Table 6. The time span is now only 1995-2002 because lead values are used. Looking at the results, the coefficients of horizontal and forward spillover variables in both cases are strongly significant and positive. They indicate that investors are really influenced by the overall increase of the sales growth rate and they tend to go either to sectors with an expected higher sales growth rate or to sectors that are downstream from these growing sectors. ${ }^{10}$

Accordingly, the results provide sufficient reason to assume that foreign investment is not completely exogenous and that it is necessary to control for this endogeneity, which stems from not being able to control for the ex ante industry growth opportunity. Some headway can be achieved by finding a variable that is correlated with the sales growth rate but is not correlated with foreign investment. A natural choice is to look abroad and find this variable in the remaining Visegrad Four (V4) countries. ${ }^{11}$ The economies of these countries are linked with the Czech economy and if there is a boom in one of these country's industries, it is very likely that this boom is also in the industry across the border. Table 7 summarizes the results from the regressions of Czech production on production in the remaining V4 countries, both in level and log form. These results suggest that the Czech economy is closely linked to the economies of Hungary and Slovakia, while the linkage with Poland is much weaker. However, Hungary and Poland are not suitable as proxies because they became attractive to foreign investors much sooner than

\footnotetext{
${ }^{10}$ This claim is further supported by regressing the lead horizontal spillover variable on the sales growth rate when the corresponding coefficient is positive and strongly significant. Similarly, I find the same result when using the lead forward spillover instead.

${ }^{11}$ Hungary, Poland, and Slovakia.
} 
the Czech Republic and their production is already impacted by FDI. ${ }^{12}$ The only suitable country remains Slovakia. Foreign investment in Slovakia lags behind the Czech Republic by $4-5$ years with the main investment boom starting in 2002 . Thus, the production growth rate in Slovakia is not affected by the massive foreign investment almost during the whole time span used in this paper. It can be used for forecasting a "natural" level of production ${ }^{13}$ in the Czech Republic which is performed by regressing Czech production on Slovak production in the years 19901997 and further predicting Czech "natural" production during the whole time span 1995-2003. Finally, this new variable is used to control for the endogeneity of FDI.

To this effect, the following modification of model (7) is estimated:

$$
\begin{aligned}
\Delta \ln S A L E S_{i j t}= & \gamma_{i}+\alpha_{1} \Delta \ln F A_{i j t}+\alpha_{2} \Delta \ln S C_{i j t}+\alpha_{3} H O R I Z_{j t}+ \\
& +\alpha_{4} B A C K_{j t}+\alpha_{5} F O R W_{j t}+\Delta \ln P R O D_{j t}^{C Z}+\alpha_{Y}+\varepsilon_{i j t},
\end{aligned}
$$

where the variable $\Delta \ln P R O D_{j t}^{C Z}$ stands for the predicted "natural" production growth rate in sector $j$ at time $t$ in the Czech Republic. The results are summarized in Table 8, again with separate columns for each sample. ${ }^{14}$ Similarly to the results corresponding to model (7), the new results indicate no significant forward spillover effects. However, contrary to previous results, the coefficient of the horizontal spillover variable is significant and negative. This implies that domestic companies are losing in the presence of foreign investors within the same industry. This result also contradicts the results from previous studies, which mostly find a positive

\footnotetext{
${ }^{12}$ Hungary was attracting FDI even before 1989, reaching its peak in 1995. FDI inflow was then declining till 2001 when it started to rise a little bit again. The FDI inflows into Poland were rather modest until 1994, but started to grow in 1995. Poland attracted a record amount of foreign investment in 2000.

${ }^{13}$ This is a level of production that is assumed to be realized by an industry in the Czech Republic, had it not received any FDI.

${ }^{14}$ Table 8 presents also the results from estimation using a population of "to-now-domestic" companies in order to verify the potential endogeneity of foreign ownership even after including the predicted "natural" production growth rate. Nevertheless, the comparison with the results from a sample of "always-domestic" companies reveals that there is still no cherry picking by foreign investors.
} 
horizontal spillover effect. Regarding backward spillovers, the coefficients are still negative and significant. Their magnitude has grown in comparison to those from the baseline specification by about $25 \%$. Thus, the evidence suggests that the previous results are biased towards positive values because of an underlying growth rate differential that is mistakenly causally linked with FDI.

According to these results, domestic companies are negatively affected by the presence of foreign investors in downstream sectors. Now the question is: what makes the sales growth rates of these companies lower? The answer can be found in Tables 10 and 11. The first column of Table 10 includes the results from a regression of import on the share of foreign capital. This regression is estimated on the sector level and the dependent variable, import, represents the amount of goods and services imported to sector $j$ at time $t$ from abroad. The positive coefficient at $H O R I Z_{j t}$ suggests that foreign investors tend to import their supplies from abroad rather than use domestic suppliers. In addition, according to the first two columns of Table 11, domestic companies oriented to the foreign market are able to deal with it. ${ }^{15}$ Although the corresponding coefficient of the backward spillover variable is negative, it is statistically insignificant. However, domestic companies oriented mostly on the domestic market have nobody else to supply. In this case, there is a significant and negative backward spillover effect. Since the number of these domestically-oriented companies is bigger than the export-oriented, this negative effect dominates when the sample of all "always-domestic" companies is employed.

\subsection{FDI Spillovers on Various Subsamples}

The previous results indicate that there are strong backward spillover effects from FDI on domestic companies. Horizontal spillover effects are present as well but they are much less statistically or economically significant. Additionally, there are

\footnotetext{
${ }^{15}$ The regression in Table 11 is run on the firm level, although companies are divided into exportand non-export-oriented groups based on data on the sector level. A sector is considered to be export-oriented if it exports on average over the period 1995-2003 at least $50 \%$ of its production abroad.
} 
no forward spillovers present. However, these effects may be prevalent or stronger only in some period of time or in some specific group of companies. Fortunately, the sample used in this paper is sufficiently big, which allows creating several smaller subsamples. Thus, regression (9) is run stepwise on samples from the periods 19951997, 1998-2000, and 2001-2003. Moreover, it is run on a sample from the period 1998-2003 to see the impact of FDI on domestic companies after the start of the boom in 1998. Then, it is run also on a sample of "smaller" companies. In this case, a company is defined as "smaller at time $t$ " if its amount of fixed assets in year $t$ is lower than the average amount of fixed assets of all companies within the same sector in the same year $t$. This case is interesting because there are potentially two opposite effects. Due to their smaller size, these companies may be more flexible and able to adjust more quickly to a new situation in a market. On the other hand, precisely because of their smaller size, they have only limited sources for improving their technologies or hiring new managers. Finally, regression (9) is run on samples of only-manufacturing companies as well as only-service companies to see the impact of FDI on these specific industries.

The results of the estimated coefficients from the seven regressions on subsamples of always-domestic companies are summarized in Table 9. The coefficients of inputs are almost the same as with the original sample. The only difference is that the coefficient of fixed assets is significant only for manufacturing sectors. The results further suggest that there are neither horizontal nor forward spillover effects of FDI in the period 1998-2003 as corresponding coefficients are non-significant. Although these effects are present in the earlier as well as the later period, they are dominated by the years 1998-2000 with no significant spillover effects at all. Negative horizontal spillovers can probably be explained by increased competition within sectors. Regarding forward spillover effects, their negative values in the years 1995-1997 and 2001-2003 can be explained by similar arguments as in the case of backward spillovers on the whole sample of always-domestic companies. According 
to Tables 10 and 11, foreign companies tend to export their products abroad which makes consuming domestic companies that are oriented to the domestic market suffer. Although the last columns in Table 11 are related to the period 2001-2003, the results are qualitatively the same also for the period 1995-1997. On the other hand, positive backward spillovers in the years 2001-2003 can be assigned to the increased effort of domestic companies to satisfy their foreign customers.

Here it is necessary to emphasize that although significant spillovers are present also during the years 1995-1997, the question of their potential presence is much more interesting afterwards, i.e., in the period characterized by government subsidies as well as huge FDI inflows.

The situation for "smaller" companies just copies the overall results with only negative backward spillovers. Thus, as regards the potential opposite effects mentioned above, the effect of "smaller" companies' limited sources dominates their flexibility. While the results for manufacturing companies do not reveal any significant spillovers, the last column shows that especially the service sector is the one that suffers in the presence of foreign investors. Both horizontal and backward spillovers are negative. This is a natural result because service companies are almost completely domestically oriented and usually they are not forced by the domestic market to improve their products. Therefore, it is even harder for them to adjust to the presence of foreign companies. However, surprisingly, forward spillovers are found to be positive, which might suggest an ability of domestic companies to improve themselves once they are offered products and services from foreign companies from upstream sectors.

\subsection{Time Aspects of FDI Spillovers}

The sections above assume that horizontal and vertical spillover effects are constant over time. But it is reasonable to assume that since foreign investors are usually one step ahead of domestic companies, these domestic companies need some time 
to improve their technology or efficiency. Moreover, the inflow of FDI has increased substantially since 1998, but this increase takes some time to have an effect. It is often the case, particularly for big investments, that although they are assigned to one specific year, it takes 1-2 years till these new companies start to produce and consequently to have an impact on a market.

Therefore, in order to allow for the lagged effects of horizontal and vertical spillovers, the modification of model (9), already with the lagged variables $H O R I Z$, $B A C K$, and $F O R W$, is estimated. The estimation results are reported in Table 12. The horizontal spillover effects are now found to be significantly negative only from the 2-year lag, which suggests that it takes some time for the sales growth rate of domestic companies to decrease. Hence, initially these companies are affected by the presence of foreign companies within their sector only slightly as the estimated horizontal spillover effects at time $t$ and $t-1$ are either weakly significant or not significant at all. But after 2-3 years they start to lose their positions in the market, probably due to increased competition. Regarding backward spillovers, all lagged effects are found to be significant and negative, so domestic companies do not benefit from supplying products or services to foreign companies and rather the opposite is true. No forward spillover effects are found. Thus, vertical spillover effects are not sensitive to time and they occur within the same year as a foreign investment.

\section{Conclusion}

In this paper I analyze the spillover effects of FDI on the sales growth of domestic Czech companies over the period 1995-2003. Besides estimating the "standard" horizontal spillovers, I also focus on vertical spillovers, i.e., the FDI indirect effects on supplying or purchasing domestic companies from other sectors. Moreover, this study allows also for the possible endogeneity of FDI with respect to future industry growth. 
Contrary to the arguments supporting the subsidization of FDI, this paper finds that foreign investors contribute negatively to the performance of domestic companies. The results suggest the presence of negative backward and horizontal spillover effects from FDI. A 1\% increase in foreign capital in a downstream sector causes a decrease in the growth rate of sales of supplying domestic companies by more than 1.8 percentage points. On the other hand, horizontal effects are statistically weaker and much smaller in magnitude. The decrease is twelve times smaller. No forward spillover effects are present. These results imply that domestic companies are not able to sustain increased competition within a sector and their sales growth decreases. Moreover, supplying domestic companies do not gain from the presence of foreign companies. The evidence can be explained by the fact that foreign companies tend to import their supplies from abroad instead of using domestic suppliers. As a consequence, those domestic companies that are oriented mainly on the domestic market lose their sales. Both of these negative spillovers are present especially in service sectors, which is again the consequence of their mainly domestic orientation. However, once they are offered "better" products from upstream sectors with a foreign presence, their sales growth increases.

Furthermore, I consider also the time aspect of these spillovers. In this case, the results show that horizontal spillover effects are present mainly towards the end of the sample frame. The situation is similar also for forward spillover effects. On the other hand, the sales growth of supplying domestic companies starts to increase towards the end of the sample frame. This evidence can be assigned to the increased effort of domestic companies to satisfy their foreign customers. As regards the potential lagged spillover effects, they are confirmed only for horizontal spillovers. They lag behind an actual investment by two years. On the contrary, backward spillover effects are not sensitive to time and their effect is immediate in the same year.

In this paper I conclude that foreign investors contribute negatively to the per- 
formance of domestic companies. However, one should not understand these results as suggesting to not encourage FDI. Besides the evidence that companies receiving foreign investment are typically characterized by higher productivity (Javorcik and Arnold 2005), there are other numerous positive effects, e.g., newly built highways or newly created job positions, that would be difficult to evaluate. Nevertheless, they are undoubtedly beneficial economically as well as socially.

\section{References}

Aitken, B. J., \& Harrison, A. E. (1999). Do Domestic Firms Benefit from Direct Foreign Investment? Evidence from Venezuela. American Economic Review, 89(3), 605-618.

Bena, J., \& Hanousek, J. (2006). Rent Extraction by Large Shareholders: Evidence Using Dividend Policy in the Czech Republic. CERGE-EI Working Paper, 291.

Damijan, J. P., Knell, M., Majcen, B., \& Rojec, M. (2003a). The Role of FDI, R\&D Accumulation and Trade in Transferring Technology to Transition Countries: Evidence from Firm Panel Data for Eight Transition Countries. Economic Systems, 27(2), 189-204.

Damijan, J. P., Knell, M., Majcen, B., \& Rojec, M. (2003b). Technology Transfer through FDI in Top-10 Transition Countries: How Important are Direct Effects, Horizontal and Vertical Spillovers? WDI Working Paper, 549.

Djankov, S., \& Hoekman, B. (2000). Foreign Investment and Productivity Growth in Czech Enterprises. The World Bank Economic Review, 14(1), 49-64.

Earnhart, D., \& Lízal, L. (2002). Effects of Ownership and Financial Status on Corporate Environmental Performance. CEPR Discussion Paper, $355 \%$. 
Görg, H., \& Greenaway, D. (2003). Much Ado about Nothing? Do Domestic Firms Really Benefit from Foreign Direct Investment? IZA Discussion Paper, 944.

Haddad, M., \& Harrison, A. (1993). Are there Positive Spillovers from Direct Foreign Investment? Evidence from Panel Data for Morocco. Journal of Development Economics, 42, 51-74.

Hanousek, J., Kočenda, E., \& Švejnar, J. (2005). Origin and Concentration: Corporate Ownership, Control and Performance. CERGE-EI Working Paper, 259.

Haskel, J. E., Pereira, S. C., \& Slaughter, M. J. (2002). Does Inward FDI Boost the Productivity of Domestic Firms? NBER Working Paper, 8724.

Jarolím, M. (2001). Foreign Direct Investment and Productivity of Czech Manufacturing Firms. CERGE-EI Dissertation.

Javorcik, B. S. (2004). Does Foreign Direct Investment Increase the Productivity of Domestic Firms? In Search of Spillovers through Backward Linkages. American Economic Review, 94(3), 605-627.

Javorcik, B. S., \& Arnold, J. (2005). Gifted Kids or Pushy Parents? Foreign Acquisitions and Plant Performance in Indonesia. Policy Research Working Paper Series, 3597, The World Bank.

Kinoshita, Y. (2000). R\&D and Technology Spillovers via FDI: Innovation and Absorptive Capacity. WDI Working Paper, 349.

Kosová, R. (2004). Do Foreign Firms Crowd Out Domestic Firms? Evidence from the Czech Republic. University of Michigan Business School Dissertation.

Kosová, R., \& Ayyagari, M. (2006). Does FDI Facilitate Domestic Entrepreneurship? Evidence from the Czech Republic. School of Business, GWU Working Paper, 8. 


\section{Appendix}

\section{Data cleaning and filling procedures}

Starting with the original data set I perform the following procedures:

- sales, fixed assets, staff costs

- Observations other than from December 31 are dropped.

- If there are more observations (from various accounting systems) for the same company and year I use only the one from the most frequent accounting system.

- Negative or missing values are replaced by interpolated values.

- Data set now comprises 24, 276 firms, 102, 871 records in total.

\section{- ownership structure}

- The sum of weighted averages, according to the number of reported days out of 365, of all owners within a year is used for creating a company's ownership structure. This structure afterwards includes the share of foreign as well as domestic capital for each company in each particular year.

- There is an assumption that if in two consecutive years $(t$ and $t+1)$ the share of domestic capital does not change and the value of the share of foreign capital in time $t$ is missing, then this missing value is replaced with the value of foreign share from time $t+1$.

- There is also an assumption of non-decreasing foreign share which allows considering a company as foreign also in the next years even without a known ownership structure once it is found to be foreign in any previous year with a known ownership structure.

- Observations from the years 1993, 1994, and 2004 are dropped due to missing ownership information.

- Data set now comprises 5, 040 firms, 28, 276 records in total.

\section{- cleaning of variables}

- If there are still some negative or missing values of sales, staff costs, or fixed assets, they are dropped.

- Companies with only one year-observation are dropped since it is not possible to count any growth rate for them.

- If the sum of percentage ownerships of foreign and domestic owners is greater than $110 \%$, these observations are dropped (this allows for a certain level of inaccuracy in ownership reporting and measurement error while counting ownership structure). 
- Negative values of ownership shares are dropped.

- Sectors with a strong regulatory role of the government are dropped:

* NACE-01 Agriculture, hunting and related service activities

* NACE-02 Forestry, logging and related service activities

* NACE-05 Fishing, fish farming and related service activities

* NACE-40 Electricity, gas, steam and hot water supply

* NACE-41 Collection, purification and distribution of water

* NACE-75 Public administration and defence; compulsory social security

* NACE-80 Education

* NACE-85 Health and social work

- The final data set now has 4,067 firms (21,357 records in total) from 43 sectors.

\section{Tables and Figures}

Figure 1: FDI inflow into the Czech Republic.

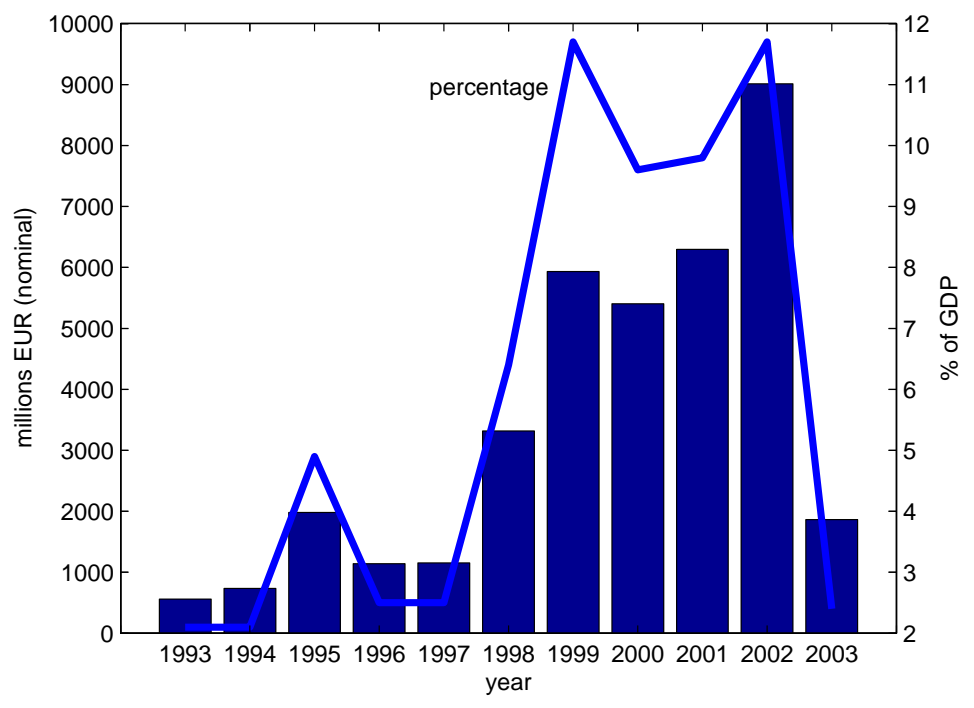

Source: Czech National Bank 


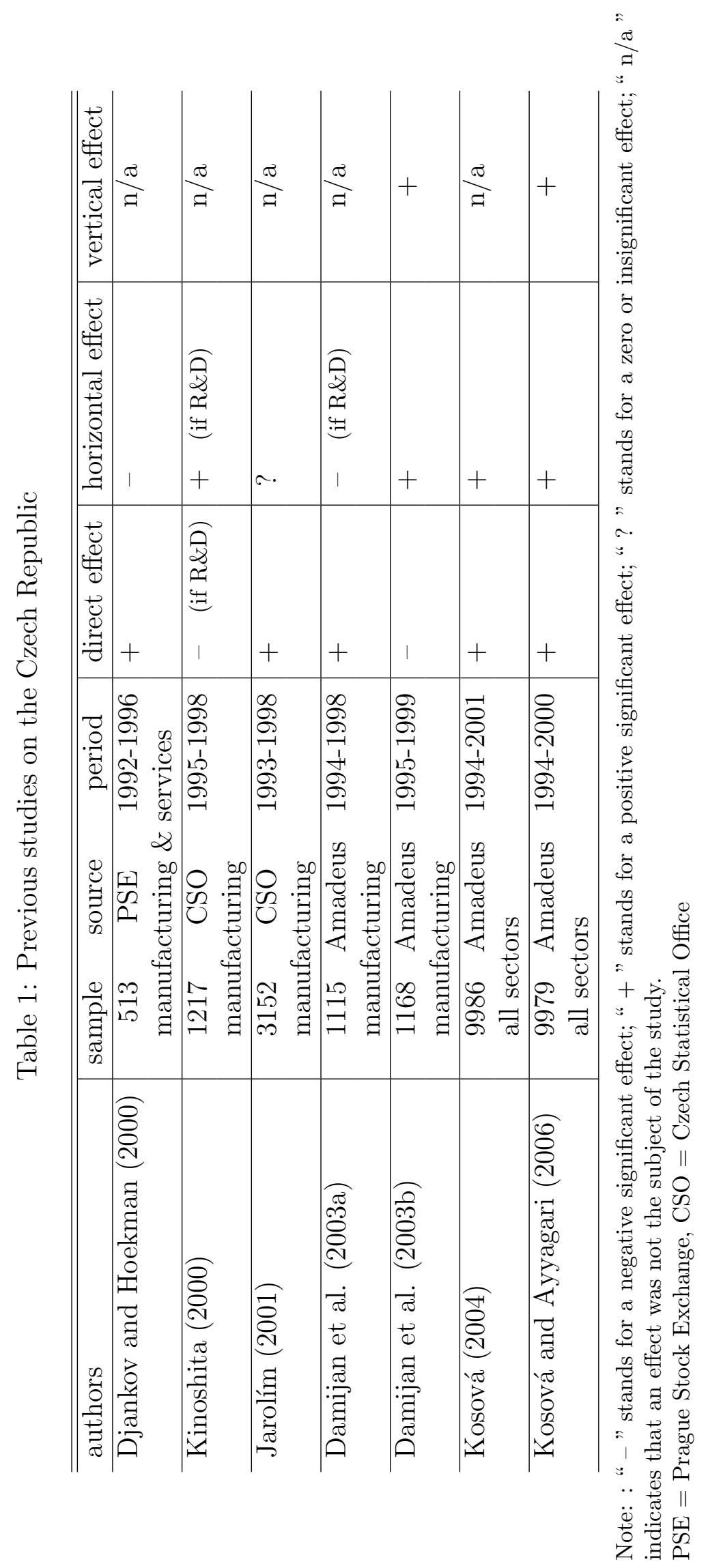


Table 2: Number of companies by year.

The column "frequency" includes information about the number of companies from each year; the column "foreign" includes the number of foreign companies within each year; and the column "new acquisitions" includes the number of companies that were acquired in each year. Percentage columns include the shares of the previously mentioned companies from the total number of companies from each year ("frequency" column).

\begin{tabular}{l|rrcrc}
\hline \hline year & frequency & foreign & foreign (\%) & new acquisitions & new acquisitions (\%) \\
\hline 1995 & 1336 & 127 & $10 \%$ & 0 & $0.0 \%$ \\
1996 & 2007 & 273 & $14 \%$ & 2 & $0.1 \%$ \\
1997 & 2370 & 400 & $17 \%$ & 43 & $1.8 \%$ \\
1998 & 2570 & 507 & $20 \%$ & 26 & $1.0 \%$ \\
1999 & 2682 & 636 & $24 \%$ & 33 & $1.2 \%$ \\
2000 & 2788 & 777 & $28 \%$ & 42 & $1.5 \%$ \\
2001 & 2644 & 838 & $32 \%$ & 38 & $1.4 \%$ \\
2002 & 2599 & 910 & $35 \%$ & 30 & $1.2 \%$ \\
2003 & 2361 & 833 & $35 \%$ & 17 & $0.7 \%$ \\
\hline Total & 21357 & 5301 & $25 \%$ & 231 & $1.1 \%$ \\
\hline
\end{tabular}

Table 3: Summary statistics.

The variable foreign denotes the share of foreign capital in a company and the variable domestic denotes the share of domestic capital in a company.

\begin{tabular}{l|rrrrr}
\hline \hline variable & observations & mean & std. deviation & min & max \\
\hline sales (ths. CZK) & 21357 & 609828 & 2988393 & 1 & 154000000 \\
fixed assets (ths. CZK) & 21357 & 410742 & 2863921 & 0 & 130000000 \\
staff costs (ths. CZK) & 21357 & 69257 & 279567 & 0 & 8153205 \\
$\Delta \ln$ sales & 21357 & -0.004 & 0.952 & -10.979 & 14.458 \\
$\Delta \ln$ fixed assets & 21357 & 0.038 & 0.748 & -9.543 & 11.785 \\
$\Delta \ln$ staff costs & 21357 & 0.069 & 0.621 & -9.641 & 11.785 \\
$\Delta \ln$ CZ production & 20365 & 0.021 & 0.040 & -0.128 & 0.300 \\
foreign (\%) & 21357 & 18.807 & 36.447 & 0 & 100.275 \\
domestic (\%) & 21357 & 36.718 & 39.845 & 0 & 109.678 \\
horizontal & 21357 & 0.219 & 0.185 & 0 & 1 \\
backward & 21357 & 0.140 & 0.097 & 0.001 & 0.633 \\
forward & 21357 & 0.135 & 0.083 & 0.014 & 0.419 \\
\hline
\end{tabular}


Table 4: Number of companies by NACE classification.

This table presents the classification of companies according to NACE and the type of ownership. The column "frequency" includes the total number of all companies in each sector; the column "greenfield" denotes the number of companies in each sector that are foreign for the whole time; the column "domestic" on the other hand denotes only always-domestic companies in each sector; and the column "takeover" comprises the number of companies in each sector that change ownership from domestic to foreign.

\begin{tabular}{|c|c|c|c|c|}
\hline NACE & frequency & greenfield & domestic & takeover \\
\hline 10 Mining of coal and lignite; extraction of peat & 10 & 0 & 9 & 1 \\
\hline 14 Other mining and quarrying & 30 & 0 & 25 & 5 \\
\hline 15 Manufacture of food products and beverages & 273 & 12 & 226 & 35 \\
\hline 16 Manufacture of tobacco products & 3 & 3 & 0 & 0 \\
\hline 17 Manufacture of textiles & 77 & 6 & 61 & 10 \\
\hline 18 Manufacture of wearing apparel; dressing and dyeing of fur & 14 & 0 & 13 & 1 \\
\hline 19 Manufacture of leather and leather products & 12 & 0 & 10 & 2 \\
\hline 20 Manufacture of wood and wood products & 73 & 3 & 57 & 13 \\
\hline 21 Manufacture of pulp, paper and paper products & 32 & 6 & 18 & 8 \\
\hline 22 Publishing, printing and reproduction of recorded media & 43 & 6 & 28 & 9 \\
\hline 23 Manufacture of coke, refined petroleum products and nuclear fuel & 3 & 0 & 2 & 1 \\
\hline 24 Manufacture of chemicals and chemical products & 79 & 11 & 47 & 21 \\
\hline 25 Manufacture of rubber and plastic products & 53 & 14 & 25 & 14 \\
\hline 26 Manufacture of other non-metallic mineral products & 145 & 14 & 91 & 40 \\
\hline 27 Manufacture of basic metals & 72 & 2 & 57 & 13 \\
\hline 28 Manufacture of fabricated metal products & 143 & 16 & 104 & 23 \\
\hline 29 Manufacture of machinery and equipment n.e.c. & 214 & 21 & 159 & 34 \\
\hline 30 Manufacture of office machinery and computers & 2 & 2 & 0 & 0 \\
\hline 31 Manufacture of electrical machinery and apparatus n.e.c. & 94 & 18 & 55 & 21 \\
\hline 32 Manufacture of radio, TV and communication equipment & 32 & 9 & 19 & 4 \\
\hline 33 Manufacture of medical, precision and optical instruments & 37 & 5 & 28 & 4 \\
\hline 34 Manufacture of motor vehicles, trailers and semi-trailers & 60 & 15 & 27 & 18 \\
\hline 35 Manufacture of other transport equipment & 28 & 1 & 19 & 8 \\
\hline 36 Manufacture of furniture; manufacturing n.e.c. & 32 & 4 & 20 & 8 \\
\hline 37 Recycling & 14 & 0 & 14 & 0 \\
\hline 45 Construction & 215 & 7 & 182 & 26 \\
\hline 50 Sale, maintenance and repair of motor vehicles and motorcycles & 98 & 20 & 75 & 3 \\
\hline 51 Wholesale trade, except of motor vehicles and motorcycles & 608 & 240 & 316 & 52 \\
\hline 52 Retail trade; repair of personal and household goods & 174 & 55 & 107 & 12 \\
\hline 55 Hotels and restaurants & 67 & 9 & 53 & 5 \\
\hline 60 Land transport; transport via pipelines & 104 & 4 & 93 & 7 \\
\hline 63 Supporting and auxiliary transport activities; travel agencies & 48 & 17 & 23 & 8 \\
\hline 64 Post and telecommunications & 43 & 18 & 17 & 8 \\
\hline 65 Financial intermediation, except insurance and pension funding & 202 & 35 & 148 & 19 \\
\hline 67 Activities auxiliary to financial intermediation & 17 & 3 & 13 & 1 \\
\hline 70 Real estate services & 253 & 25 & 204 & 24 \\
\hline 71 Renting of machinery and equipment without operator & 12 & 5 & 6 & 1 \\
\hline 72 Computer and related services & 80 & 30 & 43 & 7 \\
\hline 73 Research and development & 28 & 2 & 24 & 2 \\
\hline 74 Other business services & 443 & 78 & 324 & 41 \\
\hline 90 Sewage and refuse disposal, sanitation and similar activities & 63 & 3 & 56 & 4 \\
\hline 92 Recreational, cultural and sporting activities & 31 & 4 & 26 & 1 \\
\hline 93 Other service activities & 6 & 0 & 6 & 0 \\
\hline Total & 4067 & 723 & 2830 & 514 \\
\hline
\end{tabular}


Table 5: Baseline specification.

This table presents the estimated horizontal and vertical spillover effects of FDI. The dependent variable is $\triangle \ln S A L E S$. The first column with results represents the model with spillovers examined on the sample of always-domestic companies, the second one represents spillovers estimated on the sample of to-now-domestic companies, and the last one shows the results using the sample of all companies.

\begin{tabular}{l|lll}
\hline \hline & always-domestic & to-now-domestic & whole population \\
\hline const & $0.289^{* * *}$ & $0.292^{* * *}$ & $0.335^{* * *}$ \\
$\Delta \ln F A$ & $(0.037)$ & $(0.035)$ & $(0.035)$ \\
& $0.072^{* * *}$ & $0.070^{* * *}$ & $0.053^{* * *}$ \\
$\Delta \ln S C$ & $(0.021)$ & $(0.021)$ & $(0.019)$ \\
& $0.594^{* * *}$ & $0.603^{* * *}$ & $0.634^{* * *}$ \\
Horizontal & $(0.046)$ & $(0.046)$ & $(0.042)$ \\
& -0.115 & -0.105 & -0.087 \\
Backward & $(0.091)$ & $(0.090)$ & $(0.077)$ \\
& $-1.533^{* * *}$ & $-1.521^{* * *}$ & $-1.871^{* * *}$ \\
Forward & $(0.284)$ & $(0.279)$ & $(0.251)$ \\
& -0.406 & -0.372 & -0.561 \\
Year dummies & $(0.355)$ & $(0.365)$ & $(0.346)$ \\
\hline number of obs. & 15202 & yes & yes \\
F statistic & 50.10 & 16056 & 21357 \\
\hline
\end{tabular}

Note: Regressions with firms' fixed effects. Robust standard errors are in parentheses; they have been corrected for clustering for each company; significance at the 1\%, 5\%, and $10 \%$ levels is denoted by $* * *, * *$, and $*$, respectively.

Table 6: The specification with lead flow of FDI.

This table presents the estimated horizontal and vertical spillover effects of foreign investment that will flow into the Czech Republic in the next year. The dependent variable is $\Delta \ln S A L E S$.

\begin{tabular}{l|ll}
\hline \hline & always-domestic & whole population \\
\hline const & $0.182^{* * *}$ & $0.211^{* * *}$ \\
& $(0.031)$ & $(0.029)$ \\
& $0.073^{* * *}$ & $0.062^{* * *}$ \\
$\Delta \ln S A$ & $(0.028)$ & $(0.023)$ \\
& $0.614^{* * *}$ & $0.650^{* * *}$ \\
Inflow Horizontal & $(0.054)$ & $(0.051)$ \\
& $0.380^{* * *}$ & $0.237^{* *}$ \\
Inflow Backward & $(0.142)$ & $(0.120)$ \\
& -0.185 & -0.167 \\
Inflow Forward & $(0.389)$ & $(0.313)$ \\
& $1.274^{*}$ & $0.990^{*}$ \\
Year dummies & $(0.661)$ & $(0.558)$ \\
\hline number of obs. & yes & yes \\
F statistic & 11329 & 15592 \\
\hline
\end{tabular}

Note: Regressions with firms' fixed effects. Robust standard errors are in parentheses; they have been corrected for clustering for each company; significance at the 1\%, 5\%, and $10 \%$ levels is denoted by $* * *, * *$, and $*$, respectively. 
Table 7: The relationship between production of the CR and other V4 countries.

This table presents the relationship between the level of production in the Czech Republic and the remaining Visegrad Four countries. The first column represents the level specification, while the second one represents the $\log$ specification. The dependent variable is production in the CR. Time span is 1990-2003.

\begin{tabular}{l|ll}
\hline \hline specification & level & $\log$ \\
\hline const & 5990077 & $3.132^{* * *}$ \\
& $(10300000)$ & $(1.143)$ \\
Slovakia & $2.116^{* * *}$ & $0.296^{* *}$ \\
& $(0.586)$ & $(0.117)$ \\
Poland & -0.188 & 0.198 \\
& $(0.612)$ & $(0.130)$ \\
Hungary & $0.091^{* *}$ & $0.349^{* * *}$ \\
& $(0.037)$ & $(0.119)$ \\
\hline number of obs. & 400 & 400 \\
$R^{2}$ & 0.694 & 0.787 \\
\hline
\end{tabular}

Note: Robust standard errors are in parentheses; they have been corrected for clustering for each company; significance at the $1 \%, 5 \%$, and $10 \%$ levels is denoted by ${ }^{* *},{ }^{* *}$, and ${ }^{*}$, respectively.

Table 8: Regression with forecasted Czech production growth rate.

This table presents the estimated horizontal and vertical spillover effects of FDI when accounting for natural growth in an economy using forecasted data about Czech production. The dependent variable is $\Delta \ln S A L E S$. The first column with results represents the model with spillovers examined on a sample of always-domestic companies, the second one represents spillovers estimated on a sample of to-now-domestic companies, and the last one shows the results using a sample of all companies.

\begin{tabular}{l|lll}
\hline \hline & always-domestic & to-now-domestic & whole population \\
\hline const & $0.268^{* * *}$ & $0.266^{* * *}$ & $0.305^{* * *}$ \\
& $(0.039)$ & $(0.038)$ & $(0.038)$ \\
$\ln F A$ & $0.069^{* * *}$ & $0.065^{* *}$ & $0.041^{*}$ \\
& $(0.027)$ & $(0.026)$ & $(0.023)$ \\
$\ln S C$ & $0.603^{* * *}$ & $0.616^{* * *}$ & $0.650^{* * *}$ \\
Horizontal & $(0.052)$ & $(0.052)$ & $(0.048)$ \\
& $-0.157^{*}$ & -0.140 & $-0.131^{*}$ \\
Backward & $(0.093)$ & $(0.093)$ & $(0.079)$ \\
& $-1.884^{* * *}$ & $-1.874^{* * *}$ & $-2.303^{* * *}$ \\
Forward & $(0.290)$ & $(0.284)$ & $(0.245)$ \\
& -0.319 & -0.261 & -0.385 \\
$\Delta \ln P R O D^{C z e c h}$ & $(0.357)$ & $(0.371)$ & $(0.357)$ \\
& $1.133^{* * *}$ & $1.092^{* * *}$ & $1.125^{* * *}$ \\
Year dummies & $(0.202)$ & $(0.199)$ & $(0.171)$ \\
\hline number of obs. & yes & yes & yes \\
F statistic & 12898 & 13640 & 18294 \\
\hline
\end{tabular}

Note: Regressions with firms' fixed effects. Robust standard errors are in parentheses; they have been corrected for clustering for each company; significance at the $1 \%, 5 \%$, and $10 \%$ levels is denoted by ${ }^{* * *}, * *$, and $*$, respectively. 


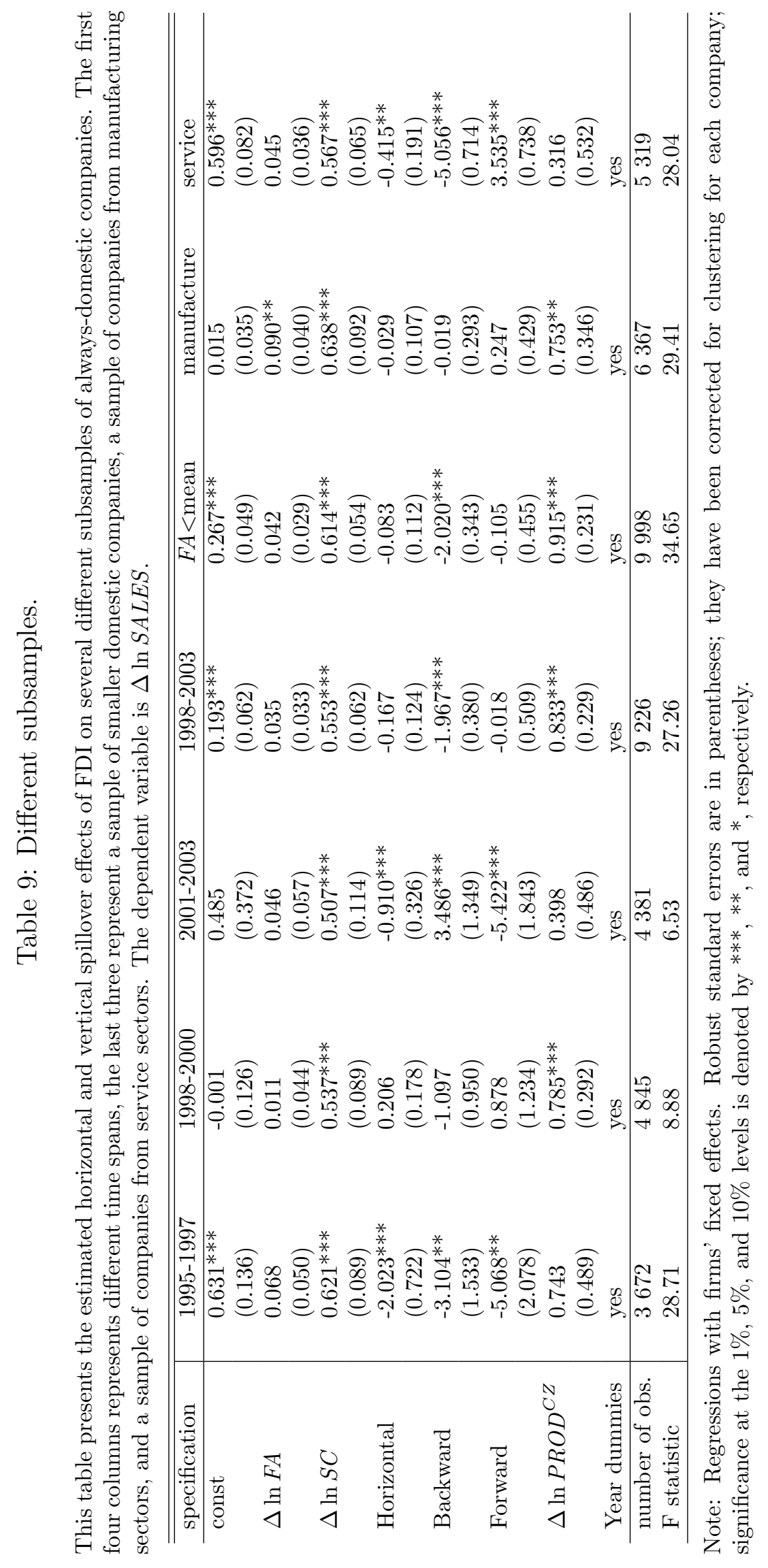


Table 10: The relationship between FDI and import (export).

This table presents the results from the regression of sector import on the share of foreign capital within the sector.

\begin{tabular}{l|ll}
\hline \hline dependent variable & $\ln I M P O R T_{j t}$ & $\ln E X P O R T_{j t}$ \\
\hline const & $8.458^{* * *}$ & $8.993^{* * *}$ \\
& $(0.191)$ & $(0.129)$ \\
$H O R I Z_{j t}$ & $1.652^{* * *}$ & $1.409^{* * *}$ \\
& $(0.468)$ & $(0.332)$ \\
\hline number of obs. & 361 & 367 \\
$R^{2}$ & 0.022 & 0.040 \\
\hline
\end{tabular}

Note: Robust standard errors are in parentheses; they have been corrected for clustering for each company; significance at the $1 \%, 5 \%$, and $10 \%$ levels is denoted by ${ }^{* * *},{ }^{* *}$, and ${ }^{*}$, respectively.

Table 11: Division by (non)exporting and (non)importing sectors.

This table presents the estimated horizontal and vertical spillover effects of FDI on several different subsamples of always-domestic companies. The division is done according to exporting and importing strategies on the sector level. The first two columns represent the division of the whole time span into non-exporting and exporting sectors; the last two represent the division of the shorter time span into non-importing and importing sectors. The former one explains the negative backward spillover effects found in regression (9), while the latter explains the negative forward spillover effects found in Table 9. The dependent variable is $\triangle \ln S A L E S$.

\begin{tabular}{l|llll}
\hline \hline sample & \multicolumn{2}{|l}{ always-domestic } & \multicolumn{2}{l}{ only years 2001-2003 } \\
sectors & non-export & export & non-import & import \\
\hline const & $0.347^{* * *}$ & $0.105^{* *}$ & 0.610 & 0.890 \\
& $(0.050)$ & $(0.042)$ & $(0.400)$ & $(1.279)$ \\
$\Delta \ln F A$ & $0.074^{* *}$ & 0.044 & 0.023 & $0.325^{* *}$ \\
& $(0.029)$ & $(0.061)$ & $(0.059)$ & $(0.159)$ \\
$\Delta \ln S C$ & $0.577^{* * *}$ & $0.715^{* * *}$ & $0.527^{* * *}$ & $0.431^{* *}$ \\
& $(0.059)$ & $(0.088)$ & $(0.134)$ & $(0.177)$ \\
Horizontal & -0.106 & $-0.269^{* *}$ & $-0.853^{* *}$ & -0.765 \\
& $(0.127)$ & $(0.109)$ & $(0.347)$ & $(1.812)$ \\
Backward & $-3.085^{* * *}$ & -0.335 & $3.509^{* *}$ & -1.145 \\
& $(0.387)$ & $(0.382)$ & $(1.394)$ & $(5.599)$ \\
Forward & 0.416 & $-1.394^{* *}$ & $-6.137^{* * *}$ & -1.594 \\
& $(0.428)$ & $(0.698)$ & $(1.966)$ & $(6.128)$ \\
$\Delta \ln P R O D^{C Z}$ & $1.040^{* * *}$ & 0.150 & 0.275 & 0.708 \\
& $(0.223)$ & $(0.330)$ & $(0.532)$ & $(1.129)$ \\
Year dummies & yes & yes & yes & yes \\
\hline number of obs. & 9980 & 2918 & 3861 & 520 \\
F statistic & 36.32 & 17.56 & 5.66 & 1.85 \\
\hline
\end{tabular}

Note: Regressions with firms' fixed effects. Robust standard errors are in parentheses; they have been corrected for clustering for each company; significance at the $1 \%, 5 \%$, and $10 \%$ levels is denoted by $* * *, * *$, and $*$, respectively. 


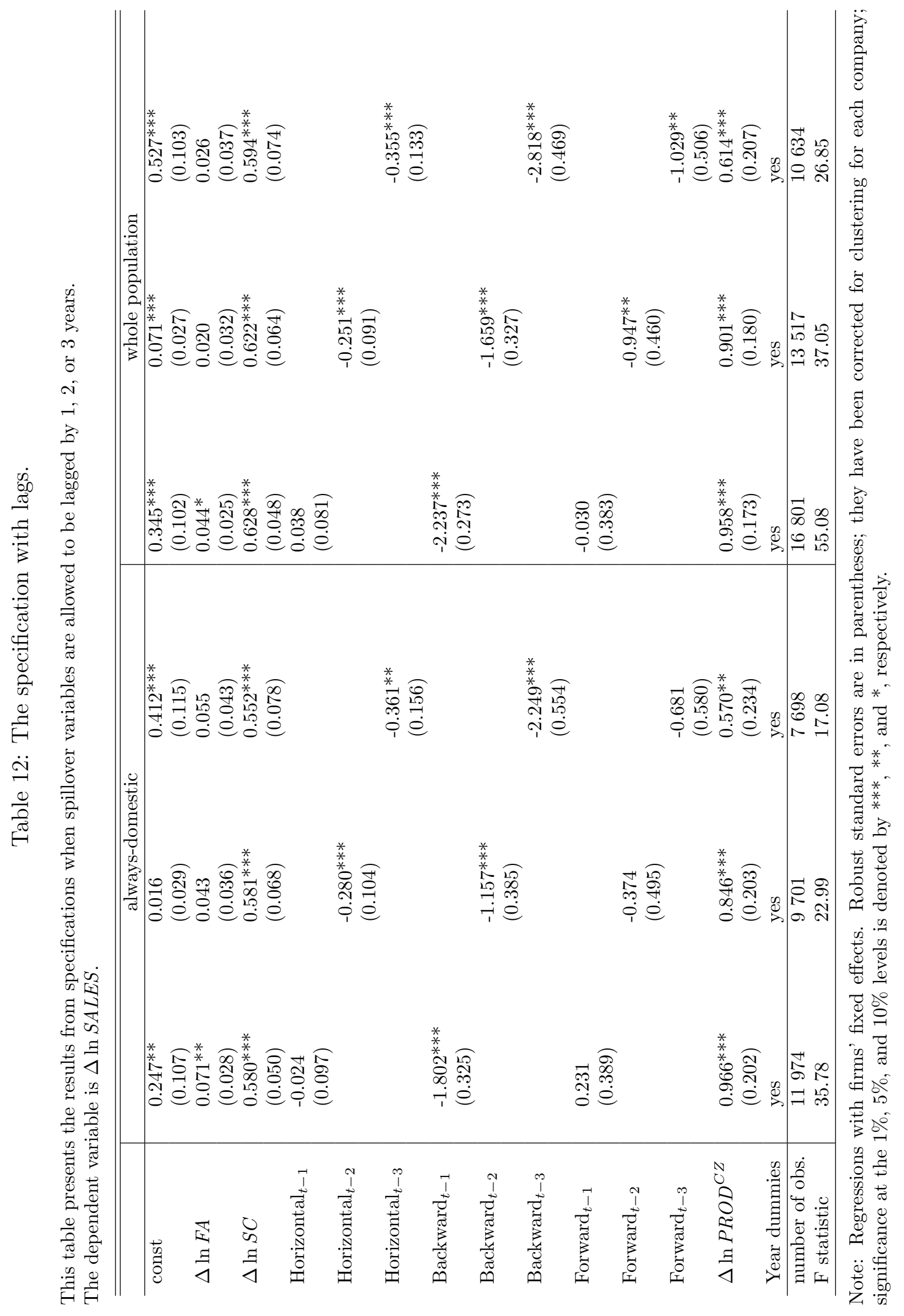


Individual researchers, as well as the on-line and printed versions of the CERGE-EI Working Papers (including their dissemination) were supported from the following institutional grants:

- Center of Advanced Political Economy Research [Centrum pro pokročilá politickoekonomická studia], No. LC542, (2005-2009),

- Economic Aspects of EU and EMU Entry [Ekonomické aspekty vstupu do Evropské unie a Evropské měnové unie], No. AVOZ70850503, (2005-2010);

- Economic Impact of European Integration on the Czech Republic [Ekonomické dopady evropské integrace na ČR], No. MSM0021620846, (2005-2011);

Specific research support and/or other grants the researchers/publications benefited from are acknowledged at the beginning of the Paper.

(c) Juraj Stančík, 2007

All rights reserved. No part of this publication may be reproduced, stored in a retrieval system or transmitted in any form or by any means, electronic, mechanical or photocopying, recording, or otherwise without the prior permission of the publisher.

Published by

Charles University in Prague, Center for Economic Research and Graduate Education (CERGE) and

Economics Institute ASCR, v. v. i. (EI)

CERGE-El, Politických vězňů 7, 11121 Prague 1, tel.: +420 224005 153, Czech Republic.

Printed by CERGE-EI, Prague

Subscription: CERGE-EI homepage: http://www.cerge-ei.cz

Editors: Directors of CERGE and EI

Managing editors: Deputy Directors for Research of CERGE and EI

ISSN 1211-3298

ISBN 978-80-7343-139-6 (Univerzita Karlova. Centrum pro ekonomický výzkum

a doktorské studium)

ISBN 978-80-7344-128-9 (Národohospodářský ústav AV ČR, v. v. i.) 
CERGE-EI

P.O.BOX 882

Politických vězňů 7

11121 Praha 1

Czech Republic http://www.cerge-ei.cz 